\title{
Tidlig utblokking bedrer overlevelse
}

\author{
$\AA$ sende flere pasienter med hjerteinfarkt til utblokking eller hjerte- \\ kateterisering kort tid etter infarktet kan redusere dødeligheten første år \\ med $40 \%$.
}

Dødelighet etter hjerte- og karsykdom går ned både i Norge og i resten av Europa. Endringer i livsstil (færre røykere, sunnere kosthold) og behandling har betydning. Erlend Aune har studert dødelighet første år etter hjerteinfarkt hos alle pasienter som var innlagt ved Sykehuset i Vestfold i Tønsberg i årene 2003 og 2006.

- I 2003 ble de fleste pasientene med hjerteinfarkt behandlet med medisiner, og det var få som ble sendt til Rikshospitalet for utblokking av kransårene i akuttfasen, sier Aune. - Etter at det kom nye europeiske retningslinjer for behandlingen i 2005 skjedde det en endring: Pasienter med EKG-forandringer som indikerte at en kransåre var gått helt tett - såkalt «blålysinfarkt» - ble sendt direkte fra ambulanse til Rikshospitalet for akutt utblokking. Pasienter med hjerteinfarkt uten slike EKG-forandringer ble vurdert for hjertekateterisering innen 48-72 timer. Fra 2003 til 2006 ser vi en markant økning i andel pasienter med akutt hjerte- infarkt som ble sendt til utblokking kort tid etter infarktet. Dødeligheten ett år etter hjerteinfarktet ble redusert med $40 \%$ både for pasientene med «blålysinfarkt» og de andre hjerteinfarktpasientene, sier Aune.

Røykere som ble innlagt med hjerteinfarkt uten «blålys»-indikasjon hadde mye høyere dødelighet i 2003 enn i 2006, og ser ut til å ha spesielt god effekt av tidlig utblokking. Røyking var en uavhengig risikofaktor for død ved konservativ behandling, og røykere var 15-20 år yngre enn ikke-røykere ved innleggelse.

- Tidlig utblokking av kransårer som en del av vanlig rutine kan gi bedre behandlingseffekt enn det som er vist i studier på mer selekterte pasienter med hjerteinfarkt, sier Aune.

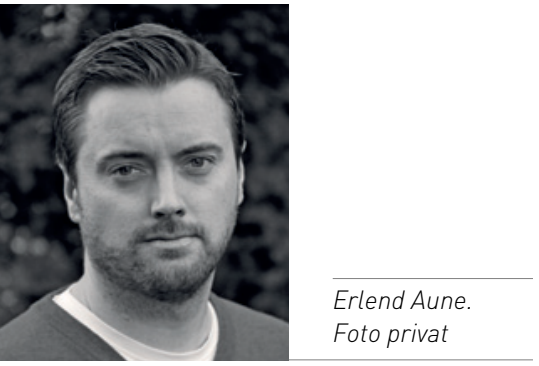

\section{Disputas}

Erlend Aune disputerte for ph.d.-graden ved Universitetet i Oslo 6.12. 2011. Tittel på avhandlingen er Acute myocardial infarction - consequences of new treatment modalities and smoking status. Observations from two prospective cohort studies.

\section{Anne Forus}

anne.forus@hotmail.com

Tidsskriftet

\section{Risikofaktorer for subaraknoidalblødning}

\section{Røyking blant kvinner er assosiert med økt risiko for subaraknoidalblød- ning. Overvekt derimot, ser ut til å kunne være en beskyttende faktor.}

Marie Søfteland Sandvei har undersøkt forekomst, dødelighet og risikofaktorer for subaraknoidalblødning. Med utgangspunkt i befolkningsundersøkelsene HUNT 1 og 2 (1984-86 og 1995-97) og Tromsø 3 og 4 (1985-87 og 1994-95) ble alle deltakere som fikk subaraknoidalblødning i perioden 1984-2007 registrert.

Sandvei og medarbeidere fant til sammen 214 pasienter og en insidens på 10,3 per 100000 personår. Insidensen var høyere hos kvinner (13,3 per 100000 personår) enn hos menn (7,1 per 100000 personår).

- Røykere hadde høyere risiko for subaraknoidalblødning enn de som aldri hadde røykt, og risikoen assosiert med røyking var høyere hos kvinner enn hos menn. Høyt blodtrykk var også forbundet med økt risiko. Overvekt derimot, var assosiert med lavere risiko for subaraknoidalblødning sammenliknet med normalvekt, forteller Sandvei.

Sandvei og medarbeidere undersøkte også om høye kolesterolverdier var assosiert med økt risiko.

- I totalpopulasjonen fant vi ingen sammenheng mellom totalkolesterol, HDLkolesterol eller triglyserider og risiko for subaraknoidalblødning. Hos unge derimot, ble risikoen redusert med økende verdi av HDL-kolesterol, sier Sandvei.

\section{Merete Kile Holtermann}

merete.holtermann@legeforeningen.no

Tidsskriftet

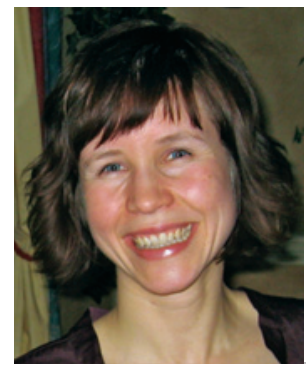

Marie Søfteland

Sandvei.

Foto privat

\section{Disputas}

Marie Søfteland Sandvei disputerte for ph.d.graden ved Norges teknisk-naturvitenskapelige universitet 4.11. 2011. Tittelen på avhandlingen er Incidence, mortality, and risk factors for aneurysmal subarachnoid hemorrhage: Prospective analyzes of the HUNT and Tromsø studies. 